\title{
MOBILE X-SPACE DESIGN, TEACHING STRATEGIES AND UNDERGRADUATE STUDENTS' COLLABORATIVE LEARNING BEHAVIOUR: A CASE STUDY IN TAYLOR'S UNIVERSITY, MALAYSIA
}

\author{
${ }^{1,3}$ Lim Chee Leong, ${ }^{1}$ Nurhanim Hassan, ${ }^{2}$ Filzah Md. Isa \& \\ ${ }^{3}$ Habibah Ab Jalil \\ 'e-Learning Academy, INTELLECT, \\ ${ }^{2}$ Taylor's Business School, Taylor's University \\ ${ }^{3}$ Faculty of Educational Studies, Universiti Putra Malaysia, Malaysia
}

Corresponding author: cheeleong.lim@taylors.edu.my

Received: 2 October 2018 Revised: 23 November 2018 Accepted: 10 December 2018

\begin{abstract}
Purpose: The availability of new innovative learning spaces together with the introduction of new teaching and learning strategies have shifted the nature of the classroom from a place of instruction towards a place that produces authentic learning. Students in the $21^{\text {st }}$ century are inclined to learn with peers, through the use technology to produce the information as the result of their collaboration. This research examines the effect of learning space design and teaching strategies on undergraduate students' collaborative learning behaviour in the Mobile X-Space classroom.
\end{abstract}

Methodology: This study used a quantitative survey research design to measure students' learning experience in the Mobile X-Space classroom. A set of online self-reported questionnaire was posted through the official Learning Management System of the university to collect data from 467 undergraduate students in a Malaysian top private university. Through exploratory factor analysis, three factors were identified: (a) teaching strategies, (b) collaborative learning behaviour and (c) space design. Pearson's correlation and multiple regression were run to assess the relationship between learning space design and teaching strategies conducted by the lecturers on the collaborative learning behaviour of the students. Two-way factorial ANOVA with Post Hoc tests were performed to determine 
the effects of gender and study semester of the students on their collaborative learning behaviour.

Findings: The results from the multiple regression analysis revealed that both (i) teaching strategies, and (ii) space design were positively correlated with collaborative learning behaviour of the students. The results from Person's correlation showed a significant, strong and positive relationship between teaching strategies conducted by the lecturers on the collaborative learning behaviour among the students. Also, there was a statistically significant, strong and positive relationship between learning space design on the teaching strategies of the lecturers. In addition, the results from two-way factorial ANOVA showed that collaborative learning behaviour was different for groups in different study semesters. However, there was no statistically significant difference for collaborative learning behaviour between different genders in all semesters.

Significance: The outcomes of this research will be beneficial in enhancing the support and design of future learning spaces and add value to the present educational model. It is also beneficial in guiding academics in determining the practical teaching and learning approaches in the flexible learning spaces, which could be more suitable for the millennium youth who are more tech-savvy and favour Internet of things in their daily lives. This type of learning space will help to improve the students' soft skills and collaborative skills, that are very useful in their future employability in the actual work settings.

Keywords: Learning spaces design, active learning, gender differences in collaborative learning, next generation learning, collaborative learning behaviour, mobile X-space.

\section{INTRODUCTION}

Higher education institutions (HEIs) are now expected to produce well-rounded students who are equipped with the $21^{\text {st }}$ century skills such as effective communication, critical thinking and creative problem solving (Ahmad Ibrahim, 2017). These students are also expected to be equipped with the right skills to be able to work collaboratively in teams and function effectively in the society. 
Continuously enhancing their learning and improving their skills are now crucial for the students to survive in this challenging world (Saavedra \& Opfer, 2012). HEIs, as the main education providers, are now pressured to relook their existing instructional delivery system and facilities that will be able to provide a conducive environment for students to enable them to respond to current changes and be equipped for the $21^{\text {st }}$ century.

One of the important areas that need to be investigated include teaching strategies such as teacher-centred, student-centred, problem-based learning and case-based learning. Although the advancements of Information and Communication Technology (ICT) have influenced the teaching and learning environment and employability skills required by the industries have changed, the teaching strategies and approaches have not advanced in tandem to address these new challenges to produce well-rounded students. This is because the teacher-centred approach is still the preferred approach throughout the world (Saavedra \& Opfer, 2012). However, students' ways of learning have gone through various phases of changes. Of late, online learning together with borderless communication has made peer learning gain more popularity. As a result, lecturers are no longer the main providers of knowledge but are considered more as the facilitators of the students' learning process.

Apart from the teaching strategies, the design of learning environments also plays an important role for students to acquire and practise the new skills. HEIs will need to reconsider the design of the instructional spaces in order to meet this requirement. The traditional classroom with a fixed lecture-style layout will no longer be relevant and able to support students' new way of learning. It may not be able to deliver what the students are expected to learn either (Oblinger, 2007). As a result, many universities around the world are reconsidering and allocating resources for new learning spaces that will be able to support students' active learning (Harvey \& Kenyon, 2013). Most of the research on learning spaces deal with the design of the space. However, very limited number of researches have explored and investigated what is happening inside these learning spaces, especially where collaborative learning is concerned.

This research therefore aims to investigate the effects of learning space design and teaching strategies on undergraduate students' collaborative learning behaviour in a classroom setting. This 
study was conducted at Taylor's University, which is the first university in Malaysia to transform its classrooms into flexible collaborative learning spaces. It is hoped that the outcomes of this research will contribute to chart a clearer understanding of how the design of these learning spaces and the teaching strategies used by the lecturers will help students learn more effectively and thus add to the stream of literature $s$ in the learning spaces studies.

\section{LITERATURE REVIEW}

The three important factors in this study are teaching strategies, learning space design and students' collaborative learning behaviour. Each of these factors is discussed as follows:

\section{Teaching Strategies}

Teaching strategies refer to methods used to help students learn the desired course contents and be able to develop achievable goals in the future (Armstrong, 2013). It identifies the different available learning methods to enable the academic to develop the right strategies to deal with the target students identified. Matching the teaching strategies with the students' learning styles is one of the challenges faced by most academics in improving the academic achievement (Tulbure, 2012). It requires flexibility, creativity and responsibility in order to provide an instructional environment that is able to respond to the learner's individual needs (Tulbure, 2012) and promote effective learning through strategies and skills (MdAli, Bi, Karim, \& Yusof, 2016).

Teaching strategies encompass teaching practices that orient mainly along traditional or more constructivist paradigms of teaching and learning (Cobern, 1993). Over the years, a few models of teaching have been identified, like the teacher-centred approach, the studentoriented and cognitively activating teaching strategies (Caro, et al., 2016; OECD, 2016). Although there are other teaching models of teaching being used, these three are the most common one, and some of the terms to describe these models have also been used interchangeably. For example, the Organization for Economic Co-operation and Development (OECD) has used the term "active learning" instead of the term student-oriented and teacher directed instruction is also teacher-centred learning. 
Despite many other teaching strategies being explored, teacher directed instruction remains the most common way of delivering instruction to the students (Cashin, 1995). In this method which is mainly delivered through lectures (OECD, 2016), the academic will generally control the learning process and act as the main source of knowledge. Students will practise the knowledge by routine drill to master this knowledge ( $\mathrm{Li}, 1999)$. This approach will rely on lecturers as the main source of information while students will learn individually with limited opportunity to communicate and collaborate with other students. This type of teaching strategy will lead to lesson being unattractive to the students and they will lose their interest to learn. This lecture approach will no longer be suitable as the dominant way of delivering instruction when teaching twentyfirst century skills.

As a result, many lecturers have moved from teacher-centred to student-centred learning (Meyer, 2010) which promotes active learning activities such as discussions between students and the teacher, as well as among students and their peers. The lecturer will now have a shifted role from being the instructor to be the group facilitator for collaborative knowledge creation (Brown \& Adler, 2008). Through student-centred learning or active learning, activities are also adapted to address the different needs of students in the classroom and student-led activities such as group discussion and peer assessment are-emphasized (Caro et al., 2016).

\section{Active Learning}

Active learning is one the teaching strategies that promotes students as active participants in their learning (OECD, 2016). An alternative to the conventional teaching, active learning encourages students to engage in a collaborative learning that enables them to take more responsibility for their learning and improve their critical thinking skills (Hacisalihoglu et al.,2018). Also known as student-centred learning, active learning will typically require students to work together during class, but it may also involve individual work and/ or reflection (CEI, 2018). Types of activities that can be conducted through active learning varies from short, simple activities like journal writing and paired discussions, to more complex activities and arrange them according to their level of complexity. like case studies, role plays, and structured team-based learning. Figure 1 below listed the different type of active learning: 


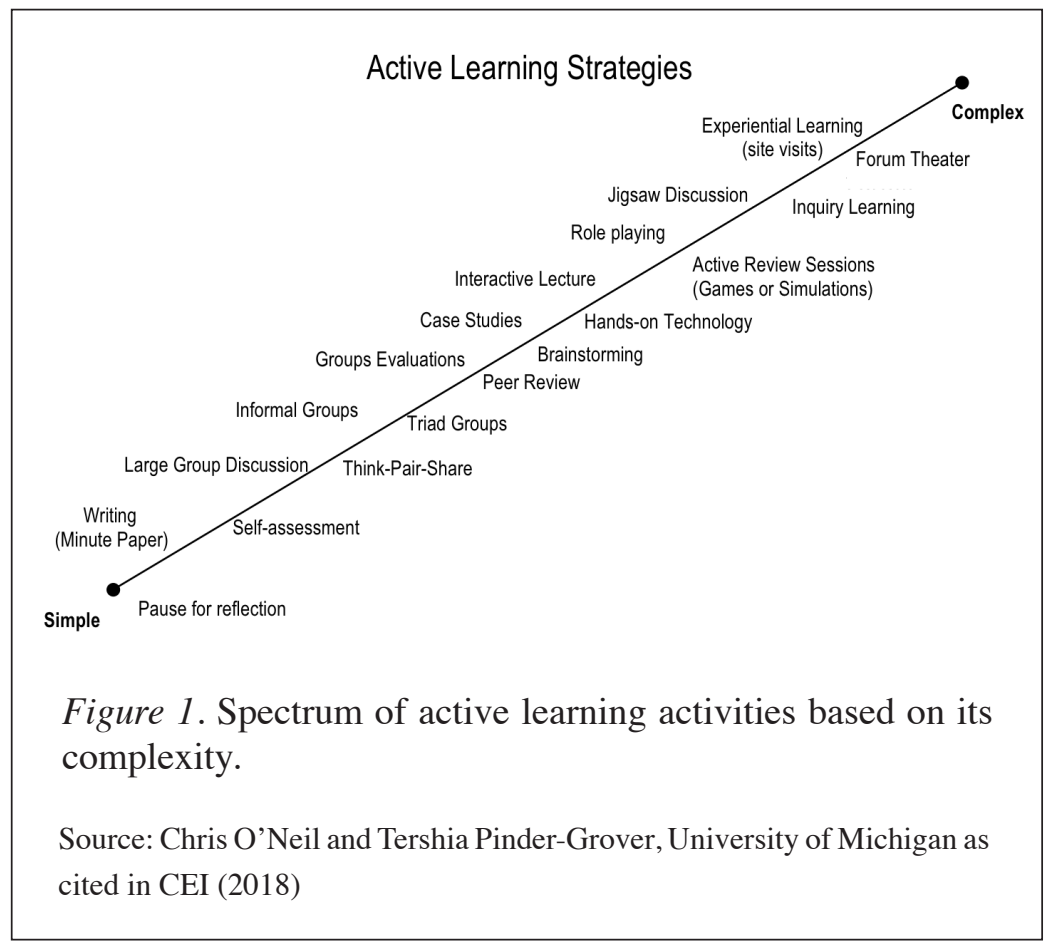

Through active learning students are made to think critically or creatively, discuss the problem with a partner, in a small group, or with the entire class, express ideas through writing, provide and receive feedback, and reflect on the learning process ((Eison, 2010).

Active learning has enabled students to be more independent learners by providing them the space to decide on their own learning strategies (Sugeng et al., 2018). In addition to these, it is also evident that the approach increased students' self-confidence as they are involved in their own intense learning process and can effectively participate and contribute to the class forum.

\section{Collaborative Learning}

Collaborative learning is an example of active learning where active engagement and interaction happen among group members of two or more, to achieve a common goal (Nokes-Malach et al, 2015). According to Smith et al (1992), collaborative learning is a broad term used to describe learning activities which involve the 
"joint intellectual effort of group of learners, or a group of learners and teachers together." In most collaborative learning situations, learners will mutually search for understanding, solutions, or meaning together. Through these interactions, students will learn from each other while utilizing resources made available through the technology. As the result, information is re-produced through these collaboration (Scott, 2015).

Research done has revealed that collaborative learning improves student achievements in their courses through formative assessment (self, individual and group assessment). It also permits students to personalize their learning experiences (Adedokun et al, 2017). In a collaborative learning environment, learners will learn to discuss their ideas with peers, exchange different points of view, question others, seek clarification, and participate in higher order thinking such as managing and organizing ideas, critical analysis, problem resolution, and the creation of new learning and deeper understanding (Scott, 2015). They will also learn to communicate their ideas and accept criticism for their ideas.

\section{Collaborative Learning Theory}

One of the learning theories that helps to explain about collaborative learning is Vygotsky's 'zone of proximal development' (ZPD) (Ahlefeldt, 2017). According to Vygotsky, in learning typically there are tasks that learners can do and there are tasks that are beyond their capabilities. Between these two areas is the zone of proximal development (ZPD), an area where a learner can learn with guidance from more knowledgeable others, technology and the tools. The Figure 2 below further illustrates the application of Vygotsky's ZPD in the classroom:

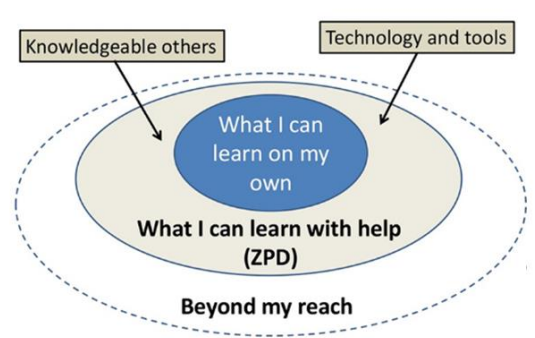

Figure 2. Vygotsky - Zone of Proximal Development.

Source: (McLeod, 2018) 
Vygotsky believes that communication and interactions with others is important in learning rather than just learn independently. Through ZPD he highlights that learning is a highly social process, and a student can learn better if guided by peers or adults or aided through different mediums, such as books, discussions, online info sources or projects where students can study, explore and develop new ideas. Collaboration is a learned process. If managed correctly, it is a powerful tool that allows lecturers to tap into new ideas and information. It provides opportunities to resolve challenge and differentiation, enhances confidence and self-esteem as well as strengthens social skills - a critical skill for life. Students who develop good social skills will go on to become very successful in life as they have the ability to deal with people and have a sharper Emotional Intelligence (EQ) (Ahlefeldt, 2017).

While there are lots of discussion on the benefits of collaborative learning in enhancing student's learning, little study is conducted on the effect of gender differences in learning. Knowing if there is any differences between male and female students in learning will surely contribute to understanding how they actually learn in collaborative learning environment.

\section{Gender Differences in Learning}

Gender is one of the personal variables that have been related to differences found in learning. Some studies show that male and female students experience learning differently regarding performance, motivation, perception, study habits, and communication behaviours (Chyung, 2007; Price, 2006). Specifically, different research studies have demonstrated the existence of different attribution patterns in males and females. For instance, Sullivan (2001) found that female students appear to respond more strongly towards online learning than their male counterparts. Rovai \& Baker (2005) also provided evidence that females felt more connected to other students in their courses, for instance, female learners felt that their online learning experiences were more aligned to their educational values and goals, able to learn independently and remain academically engaged in online environments. As a result, they may outperform their male counterparts.

On the other hand, there were studies which concluded that gender was not a significant factor to predict the learners' self-confidence, 
satisfaction (Atan et al, 2004) and learning motivation (Sulisworo, 2012). This finding is also supported by Khong et al (2017) which concluded that there was is no significant gender differences where learning Spanish as a foreign language was concerned. In terms of the learning environment, Jelas et al (2014) pointed that there was no significant difference between gender and student engagement, learning support and achievement. Moreover, Khodabandelou et al. (2014) who examined the relationship of gender on various variables claimed that although gender of undergraduate students was statistically significant, the degree of difference was not enough to moderate the relationship between the Community of Inquiry components and perceived learning in blended learning environments.

Although the studies conducted demonstrated that there is no significant gender differences in learning in normal classroom, little is known if there will be any significance finding on how these students learn collaboratively in the learning space context. While it provides opportunities for the students to work collaboratively with others, they will also be challenged to utilize the technology to find innovative solutions.

\section{Learning Spaces}

Learning spaces are now becoming an essential aspect of the learning and teaching landscape. The traditional based classroom design with teacher's desk in the front and neat rows of desks and chairs for students is no longer suitable for 21 st century learning and the new breed of Gen Z students who populate such classrooms today (Nambiar et. al., 2017). Within the last few years lecturers and administrators have started seriously considering a new classroom design to better accommodate the growing needs of students.

This learning environment should be able to support a variety of learning styles, while enabling lecturers to accommodate different students' needs. Learning spaces design will become increasingly important as learners now choose to learn in places that best suit their needs and lifestyles (Keppell in Kujawa-Holbrook, 2013). Envision ( 2107) have outlined four essential components of a $21^{\text {st }}$ century classroom: a flexible layout, technology integration, furniture for utility and light-filled environment. These elements 
are specifically incorporated into the design of these learning spaces to promote collaborative learning, the driving concept behind $21 \mathrm{st}$ century classroom design.

Previous studies on learning spaces have also revealed interesting developments in student behaviour. Students reported the new layout helped them to learn from their peers, engage in better group discussions and practise independent learning. They claimed that they were able to work in groups and learn collaboratively which helped them build their self-confidence. The social setting has a great influence on learning. this It has promoted flexible learning spaces that stimulate learning and active experimentation. It has also shifted the nature of the classroom from a place of instruction to a place that produces authentic learning (Nambiar et al, 2017).

There have been initiatives and studies carried out around the world in transforming these learning spaces. Lippincott (2009) found that most American students were more satisfied when they had experienced new learning spaces while a University of Minnesota study (Walker et al, 2011) revealed that students taught in a new learning space outperformed those taught in the traditional classroom. The Nanyang Technological University (NTU) Singapore is the first university in the South East Asia to introduce new learning spaces or smart classrooms. Since 2015, the university has gone through transformative teaching and learning delivery. It has transformed the traditional layouts of classrooms to the new smart classrooms so that students can learn more proactively and in groups, to keep up with the changing demands of workplaces. It now has more than 280 smart classrooms on campus. Facilities and infrastructure are designed to promote new teaching styles and new ways of delivering knowledge that will lead to the effectiveness of the whole learning experience. These new smart classrooms have also made new learning arrangements possible. For example, lecturers are able to flip the learning sessions where students can access course materials online before class. Class time is then used for deeper learning activities such as tackling problems in teams of five or six and engaging in more discussions with the lecturers.

Research conducted also revealed that although more HEIs are moving towards transforming their classrooms into collaborative learning spaces, each of them may have different ideas to focus on what learning spaces should be. These differences will eventually 
influence the design as well as the types of learning activities conducted in these learning spaces.

\section{Learning Spaces at Taylor's University}

Preparing students for the 21 st century is indeed a challenge. At Taylor's University, initiatives are taken to address this challenge by introducing a new classroom design to accommodate the new generation of learners. Started as part of its five-year plan (2011 2014), the University has developed and adopted six strategic thrusts. Transformational teaching and learning is one of these strategic thrusts, which focused on the two key areas; ensuring a conducive and responsive learning environment action plans, and embracing technology action plans.

Within the first key area, the university is committed to maintain the infrastructure of the campus as a learner-friendly environment. The university's facilities are maximized to promote an environment that is engaging, collaborative and flexible. While in the second key area, Taylor's University recognizes that e-Learning is an integral teaching and learning strategy. With these two key areas in mind, Taylor's University made a bold decision to transform its classroom into the collaborative classrooms, known as X-Space. Taylor's was the first university in Malaysia to transform its teaching and learning delivery. Started with only one X-Space classroom in 2012, Taylors has now converted 52 classes into the $\mathrm{X}$-Space classrooms.

$\mathrm{X}$-Space is a technology-rich, collaborative classroom specifically designed for flexible formal teaching and learning spaces. It facilitates a diverse learning experience in a highly collaborative and engaging manner. X-Space unique seating design and the availability of fast Internet connection in the classroom are planned in such a way to ensure better collaborative learning. Ideas can be easily shared and decisions can be made together more effectively throughout the learning session. It also enables digitally animated presentations for learning, thus making learning sessions more interesting and engaging. The technology used in this collaborative classroom will promote positive attitudes among students, a greater inclination to learn, and an increase in student achievement and engagement in the lessons. This learning environment will be conducive and help nurture Students' Creativity, Critical Thinking Skills and stimulate their innate curiosity. 
There are three different types of X-Space classrooms available, the HDMI, Apple and Mobile X-Space. In general, the layout of these classrooms is different from the normal classrooms. For example, instead of the normal lecture-like seating arrangement in the normal classroom, students are seated at round tables known as 'islands'. This learning space layout will automatically seat them in the group which is conducive for collaborative activities. Each table is also connected to a TV which enables them to display and share their work with their friends. The two buttons available under the TV control what can be projected on the tv display screen. The Local button will only show what is displayed by the computer that is connected to this TV while the Remote button will project what is displayed on the projector to the whole class. Lecturers will control the remote display from the lecturer's control panel situated in front of the classroom. An example of X-Space classroom is shown in Figure 2. A sample of HDMI X-Space video can also be accessed at https://youtu.be/K3WakTf5tN8.

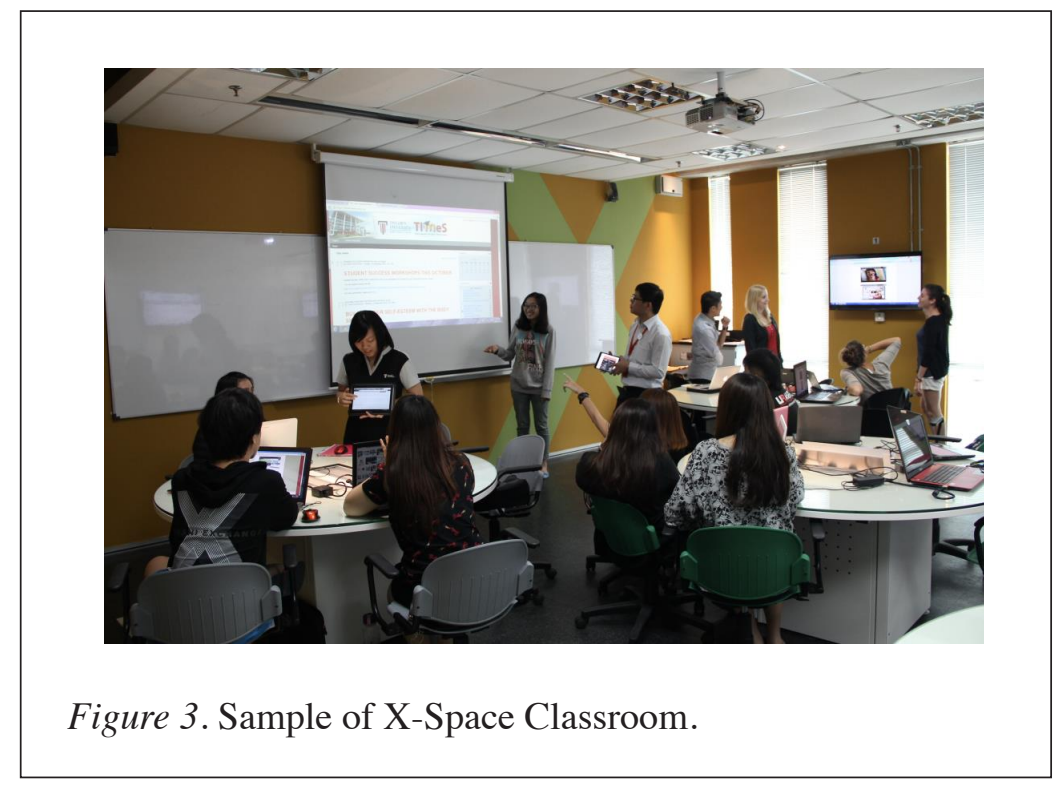

The next generation collaborative classrooms or known as the Mobile $\mathrm{X}$-Space are the latest addition to Taylor's X-Space. Compared to the HDMI and Apple X-Space, Mobile X-Space is designed without fixed furniture. It consists of movable chairs with additional storage compartments under the seats for students to keep their belongings. 
The room is also equipped with television display screens that are attached to movable stands. This setting allows academics to configure classrooms easily, making formal learning spaces more flexible to support multiple learning modes. It allows lecturers to change their classes' configurations with minimal interruption. Through Mobile $\mathrm{X}$-Space, lecturers now have the freedom and flexibility to start a class in a lecture mode, change midway for group work, and end the class with a debate mode without losing valuable time. Mobile $\mathrm{X}$-Space settings encourage active learning activities where students can move around freely for collaboration and discussion. Seeing the potential of this Mobile X-Space, Taylor's has decided to transform more classrooms into Mobile X-Space. To date, out 52 X-Space classrooms, 13 are Mobile X-Spaces. Examples of activities which can be conducted in Mobile X-Space classrooms are shown in Figure 3. A sample of Mobile X-Space can also be accessed at https://www. youtube.com/watch?v=ISMW-VDUaXI.

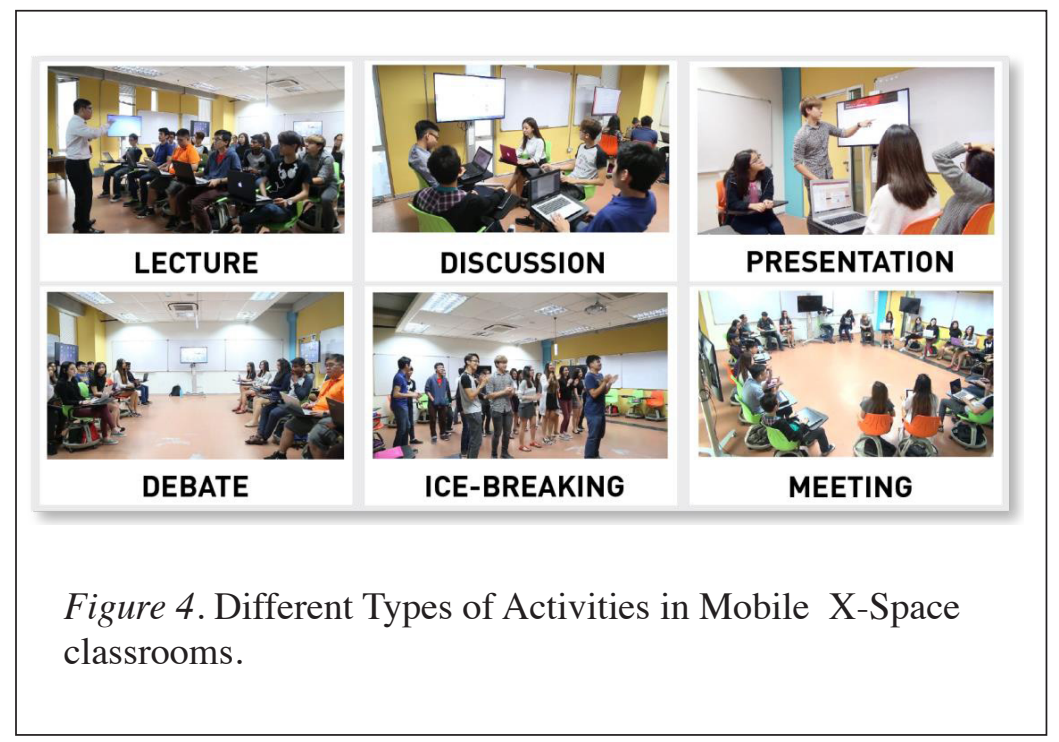

Despite the various learning spaces made available at Taylor's university, it is still a question of whether this learning space model is effective in facilitating students' learning. This study, therefore, intends to look into the effectiveness of teaching and learning activities in Mobile X-Space classes to provide the answer to this question. The effects of X-Space design on students' collaborative activities will also be explored. 


\section{CONCEPTUAL FRAMEWORK}

The conceptual framework of this study as shown in Figure 4, has been constructed based on the variables and factors derived from the literature review. It identifies the Mobile X-Space Design and Teaching Strategies as independent variables and Collaborative Learning Behaviour as the dependent variable. It also investigates the effects of gender and study semester as the moderators.

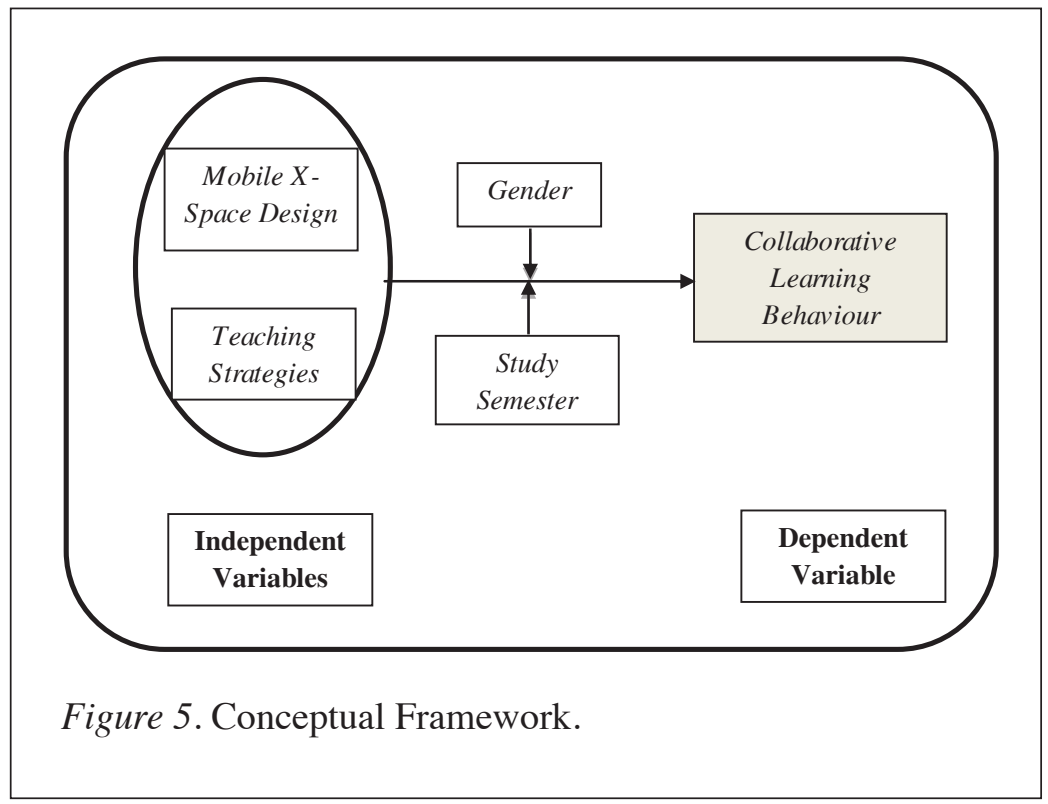

\section{RESEARCH HYPOTHESIS}

Based on the conceptual framework above, three (3) hypotheses were formulated as follows:

$\mathrm{H}_{1}$. Mobile $\mathrm{X}$-Space design is positively related to undergraduate students' collaborative learning behaviour.

$\mathrm{H}_{2}$. Teaching strategies are positively related to undergraduate students' collaborative learning behaviour.

$\mathrm{H}_{3}$. Gender and study semester affect the relationships Mobile $\mathrm{X}$-Space design and Teaching strategies have on undergraduate students' collaborative learning behaviour. 


\section{METHODOLOGY}

The overarching research question guiding this study is to examine the effects of Mobile X-Space learning design and teaching strategies on undergraduate students' collaborative learning behaviour in the Mobile X-Space classroom. More specifically, the following four research questions are examined in this study:

1. What are the dimensions of the learning experience in a collaborative learning space?

2. To what extent do teaching strategies influence students' collaborative learning behaviours?

3. To what extent does the learning space design affects students' collaborative learning behaviours in the Mobile X-Space classroom?

4. What are the effects of students' gender and study semester on their collaborative learning behaviours?

\section{Participants}

The study consisted of a sampling frame of 4,478 undergraduate students who enrolled in at least one course which was conducted in Mobile X-Space classrooms throughout the April 2018 semester. Of these students, 661 students completed the survey online resulting in a $14.76 \%$ response rate. All participants were assured that their responses would remain anonymous and confidential.

Among them, $441(66.72 \%)$ students were female, and 220 (33.28\%) students were male. The majority $(\mathrm{N}=329,49.77 \%)$ of the participants were semester 1 students. A total of 13 different academic schools were represented. More than $50 \%$ of them were from the Business School $(\mathrm{N}=241,36.46 \%)$ and Hospitality, Tourism and Events School $(\mathrm{N}=102,15.43 \%)$. See Table 1 for the detailed demographic information. 
Table 1

Description of Participants

\begin{tabular}{lcc}
\hline Demographic Variables & $\mathrm{N}$ & $\%$ \\
\hline Gender & & \\
Male & 220 & 33.28 \\
Female & 441 & 66.72 \\
Semester & & \\
One & & \\
Two & 329 & 49.77 \\
Three & 64 & 9.68 \\
Four & 66 & 9.98 \\
Five & 112 & 16.94 \\
Six & 42 & 6.35 \\
Seven & 37 & 5.60 \\
School & 11 & 1.67 \\
Business & & \\
Hospitality, Tourism and Events & 241 & 36.46 \\
Biosciences & 102 & 15.43 \\
Communication & 67 & 10.14 \\
Architecture, Building and Design & 66 & 9.98 \\
Engineering & 43 & 6.51 \\
Culinary Arts and Food Sciences & 38 & 5.75 \\
Computing and Information Technology & 30 & 4.54 \\
Liberal Arts and Sciences & 27 & 4.08 \\
Design & 22 & 3.33 \\
Law & 14 & 2.12 \\
Education & 6 & 0.91 \\
Medicine & 3 & 0.45 \\
Total & 2 & 0.30 \\
\hline
\end{tabular}

\section{Procedures}

Researchers contacted all course instructors who conducted their tutorial classes in the Mobile X-Space classrooms during the April 2018 semester. Upon the instructors' approval, researchers requested the university's Learning Management System (LMS) administrator to post an online survey in Taylor's Integrated Moodle e-Learning System (TIMeS), the university's official LMS from week 8 until 
week 12 of the semester. An email invitation with the survey link was also sent to the target participants.

Once the participants assessed the link, they were asked to read and understand the objectives of the survey before they answered the questions. At the start of the survey, participants were asked to indicate whether they have taken any courses conducted in a Mobile X-Space classroom. Participants with a Mobile X-Space experience were then led to complete the entire survey questionnaire. Completion of the survey took approximately 5-10 minutes.

\section{Instruments}

The first part of the questionnaire was developed to obtain participants' demographic information like participants' gender, semester and school of study. In the second part, responses were obtained on a 5-point Likert-type scale (1 - strongly disagree to 5 - strongly agree). This 23-item questionnaire was developed based on the peer observation conducted one semester before the data collection period. During the peer observation which was conducted between week 8 to week 14 of the semester, the early adopters and the collaborative classroom practitioners used a rubric which consists of teaching pedagogy, technology used and student collaboration to assist researchers to identify the various innovative and effective practices conducted in X-Space classrooms. This peer observation rubric used a 4-point Likert-type scale ( 1 - no evidence to 4 - extremely well observed). Also, two open-ended questions were included to identify areas for improvement in teaching and learning practices in $\mathrm{X}$-Space classrooms.

A comprehensive instrument that served the purposes of the study was developed after the peer observation had been conducted. This comprehensive instrument was compared and contrasted with another instrument developed at UPM for their internal study. To validate the consistency of the instrument, Exploratory Factor Analysis was run and the factors were re-labelled. All three extracted factors had a high level of internal consistency, as determined by a Cronbach's alpha of $0.947,0.908$ and 0.745 respectively.

\section{Data Analysis}

The analysis of the survey questionnaire data was carried out using the Statistical Package for the Social Sciences (SPSS) version 20.0 
for the descriptive analysis to describe the characteristics of the data. Outliers were assessed by inspection of a boxplot. Normality was assessed using Shapiro-Wilk's normality test (Shapiro \& Wilk, 1965) and homogeneity of variances was assessed by Levene's test. Exploratory factor analysis was conducted to reduce the large number of variables (items) to a smaller set of underlying factors that summarise the dimensions of learning experience in the Mobile $\mathrm{X}$-Space classrooms.

A multiple regression analysis was conducted to predict student's collaborative learning behaviour (CLB) based on the Teaching Strategies (TS) and Learning Space Design (LSD). Pearson's correlation was run to assess the relationship between learning space design and teaching strategies conducted by the lecturers on the collaborative learning behaviour of the students. Two-way factorial ANOVA with Post Hoc tests were performed to determine the effects of gender and study semester of the students on their collaborative learning behaviour.

\section{RESULTS}

\section{Exploratory Factor Analysis}

Research Question 1. What are the dimensions oflearning experience in a collaborative learning space?

An exploratory factor analysis was conducted to identify dimensions of learning experience in the Mobile X-Space classrooms. The principal components analysis (PCA) extraction method with oblique rotation was applied (in this case Promax). The researchers chose an oblique rotation method because each learning experience dimension was assumed to be correlated with one another. Initial analysis of the factor correlation matrix for correlations of the variables showed the correlations were comparatively high. Hence, there was overlap in variance among factors, whereby the variance warrants an oblique rotation. Therefore, Promax rotation method was performed to reduce the large number of variables (items) to a smaller set of underlying factors that summarise the essential information contained in the variables.

The suitability of PCA was assessed before the analysis. The overall Kaiser-Meyer-Olkin (KMO) measure was 0.960, far greater than 0.6. 
This shows that there are linear relationships between the variables and thus it is appropriate to run a principal components analysis. Bartlett's test of sphericity was statistically significant $(p<.0005)$, indicating that the data was likely factorizable.

Table 2

Results for KMO and Bartlett's Test

Kaiser-Meyer-Olkin Measure of Sampling Adequacy

Bartlett's Test of Sphericity

Approx. Chi-Square

7006.485

df

Sig.

PCA revealed three components, namely Teaching Strategies, Learning Space Design and Collaborative Learning Behaviour that had eigenvalues greater than one and which explained $55.39 \%, 6.48 \%$ and $5.08 \%$ of the total variance, respectively. Visual inspection of the scree plot as shown in Figure 4 indicated that three components should be retained. In addition, a three-component solution met the interpretability criterion. As such, three components were retained. The three-component solution explained $66.93 \%$ of the total variance.

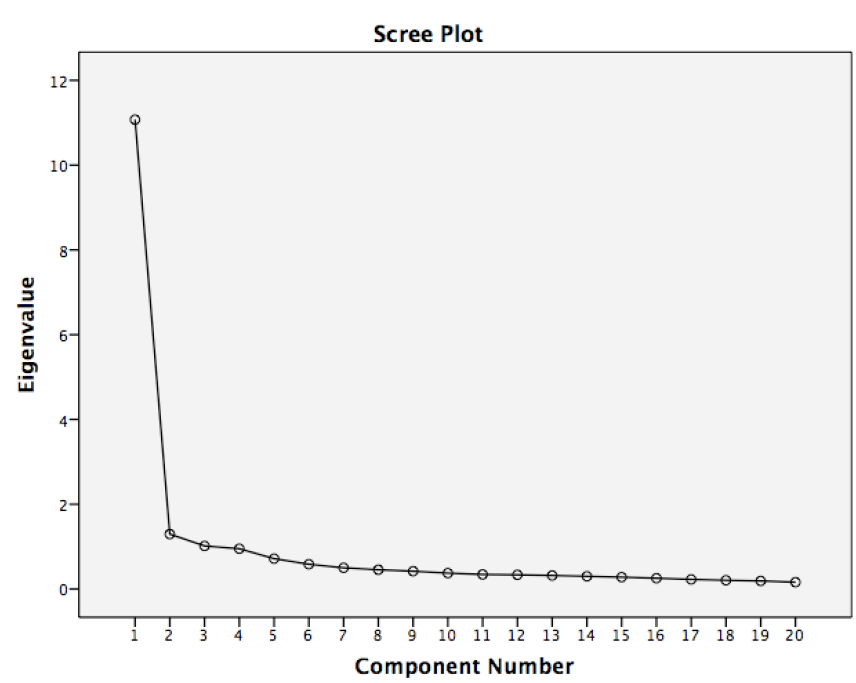

Figure 6. Screen Plot. 
Four criteria were used to arrive at the solution. First, item loadings should be above .40 . Second, any discrepancies between crossloadings with an absolute value less than .15 were deleted; third, no item was cross-loaded highly to more than one factor, for example, greater than .40 . And fourth, each factor should have at least three items (Pett, Lackey, \& Sullivan, 2003). In accordance with the items included in the factors, three (3) main components were extracted, i.e. 10 items measuring "learning and teaching strategies and activities", 5 items measuring "authentic learning behaviour" and 4 items measuring "learning space design". Out of the original 23-item measure, 4 items were deleted based on the predetermined criteria. See Table 3 for more detailed information about factor loadings, items, and Cronbach's alpha.

\section{Table 3}

Items Retained after the Exploratory Factor Analysis (EFA) and the Respective Factor Loadings

Items

Factor 1 Factor 2 Factor 3

Factor 1: Teaching Strategies

(Eigenvalue 11.07, 53.37\% of variance explained)

Problem solving $\quad .948$

Critical thinking $\quad 935$

Practical application of knowledge $\quad .907$

Applying facts through multiple media $\quad .846$

Connect various subject areas and apply them $\quad .835$

Interesting digital content $\quad .725$

Research activities to extend one's interpretation $\quad .597$

Organized and well-structured lessons $\quad .581$

Active learning $\quad .536$

Specific and detailed instructions $\quad .524$

\section{Factor 2: Collaborative Learning Behaviour}

(Eigenvalue 1.30, 6.48\% of variance explained)

Openness in discussion among peers $\quad .937$

Intellectual dialogue and debate among peers $\quad .828$

Encourage cooperation and acceptance $\quad .801$

Positive relationships among peers and $\quad .750$

instructors

Develop highly collaborative learners

.714 
Factor 3: Learning Space Design

(Eigenvalue 1.02, 5.08\% of variance explained)

Crowdedness of the classroom .703

Maintenance of the classroom

Effective class size

Conducive space for learning

\section{Analysis of Measurement Validity}

In verifying the scale for measuring these constructs, Cronbach's alpha was used to assess the reliability (Cronbach, 1951). As shown in Table 4, the coefficient alpha values were $0.947,0.908$ and 0.745 respectively. Because the Cronbach's alpha values were above the conventional level of 0.7 (Nunnally, 1978), the scales for these constructs were deemed to exhibit adequate reliability.

Table 4

Internal Consistencies for Each Factor

\begin{tabular}{lcl}
\hline Factors & N of items & a \\
\hline Teaching Strategies & 10 & .947 \\
Collaborative Learning Behaviour & 5 & .908 \\
Learning Space Design & 4 & .745 \\
\hline
\end{tabular}

\section{Multiple Regression Analysis}

\section{Research Questions 2 and 3:}

RQ2: To what extent do teaching strategies influence students' collaborative learning behaviours?

RQ3: To what extent does the learning space design affect the students' collaborative learning behaviours in the mobile $x$-space classroom?

A multiple regression analysis was performed using Teaching Strategies (TS) and Learning Space Design (LSD) as independent variables and collaborative learning behaviours (CLB) as the dependent variable to detect whether teaching strategies and learning space design factors predict collaborative learning behaviours of students (Table 5). 
The full model statistically of LSD and TS was significantly predicted CLB, $\mathrm{F}(2,464)=397.919, \mathrm{p}<.0005$. These two factors together explained $63.0 \%$ of the variability in collaborative learning behaviours (adj. $\mathrm{R}^{2}=.630$ ), is indicative of a large effect size according to Cohen's (1998) classification. The general form of the equation to predict the collaborative learning behaviour is: CLB = $-.071+.319 \mathrm{LSD}+.633 \mathrm{TS}$.

Table 5

Multiple Regression Analysis Results for Collaborative Learning Behaviour

\begin{tabular}{lcccccc}
\hline Model & $\mathrm{F}$ & $\mathrm{R}^{2}$ & Adjusted $\mathrm{R}^{2}$ & $\mathrm{~b}$ & $t$ & $\mathrm{~S}$ Sig \\
\hline Overall & 397.919 .632 & $\mathbf{. 6 3 0}$ & -.071 & -.716 & & .000 \\
Teaching & & & & .633 & 15.412 & .000 \\
Strategies & & & & & & \\
Learning & & & & .319 & 6.116 & .000 \\
Space Design & & & & & & \\
\hline
\end{tabular}

\section{Pearson Correlation Analysis}

A Pearson's correlation was run to assess the relationship between learning space design (LSD) and teaching strategies (TS) conducted by the lecturers on collaborative learning behaviours (CLB) of the students. Multi-collinearity diagnosis indicated no cause for concern, using a Variance Inflation Factor (VIF) value of 5, thus, it disclosed that the independent variables are uncorrelated.

Table 6 shows that there was a statistically significant strong positive relationship between TS on the CLB of the students, $r=$ $.776, \mathrm{p}<0.0005$, with teaching strategies explaining $60.22 \%$ of the variation in collaborative learning behaviour of the student. There was also a statistically significant strong positive relationship between LSD on the CLB of the students, $r=.666, \mathrm{p}<0.0005$, with learning space design explaining $44.36 \%$ of the variation in collaborative learning behaviour of the students. In addition, there was a statistically significant strong positive relationship between LSD on the TS of the instructors, $r=.699, \mathrm{p}<0.0005$, with learning space design explaining $48.86 \%$ of the variation in teaching strategies of the instructors in the Mobile X-Space classroom. 
Meanwhile, a Pearson's correlation was also run to assess the relationship between weekly time spent in Mobile X-Space classroom and teaching strategies conducted by the lecturers. There was a small negative correlation between weekly time spent in mobile X-Space and perceptions on the teaching and learning strategies and activities conducted by the lecturers, $r=-0.120, \mathrm{p}=0.009$.

Table 6

Pearson Correlations Among Learning Space Design, Teaching Strategies, Collaborative Learning Behaviour and Weekly Time Spent in Mobile X-Space

\begin{tabular}{lcccc}
\hline Variables & CLB & LSD & TS & Hours Spent \\
\hline CLB & 1 & & & \\
LSD & $.666^{*}$ & 1 & & \\
TS & $.776^{*}$ & $.699^{*}$ & 1 & \\
Hours Spent & -.088 & -.053 & $-.120^{*}$ & 1 \\
\hline
\end{tabular}

* Correlation is significant at the 0.005 level (2-tailed)

\section{Two-Way Factorial ANOVA}

RQ4. What are the effects of students' gender and study semester on their collaborative learning behaviours (CLB)?

The effects of gender and study semester on STUDENTS' collaborative learning behaviours (CLB) were examined using twoway factorial analyses of variance (ANOVAs). This test permits the researchers to explore both demographic data variables on the students' CLB scores. Table 7 shows the mean scores together with significant $F$ ratios. There was a statistically significant interaction between gender and study semester for the CLB scores, $F(6,453)$ $=2.762, p=.012$. However, there was no statistically significant difference for gender in all semesters.

In Table 8, Tukey post hoc analysis revealed that there was an increase in CLB scores from $2.3191 \pm 0.7182$ in the semester 1 group to 2.8382 \pm 1.2027 in the semester 5 group, an increase of 0.51916 (95\% CI, 0.0775 to 0.9608 ), which was statistically significant $(p=.010)$, but no other semester group's difference was statistically significant. In order words, only year 1 (Semester 1) and year 3 (Semester 5) students were different in their collaborative learning behaviours. 
Table 7

ANOVA Comparing Collaborative Learning Behaviours Among Different Semester Study and Gender

Dependent variable: Collaborative Learning Behaviours

\begin{tabular}{lllll}
\hline Source & $d f$ & $\begin{array}{l}\text { Mean } \\
\text { square }\end{array}$ & F & Sig. \\
\hline Gender & 1 & .864 & 1.350 & .246 \\
Semester & 6 & 2.067 & 3.227 & .004 \\
Gender * Semester & 6 & 1.769 & 2.762 & .012 \\
\hline
\end{tabular}

$\mathrm{R}$ squared $=.77($ Adjusted $\mathrm{R}$ Squared $=.050)$

Table 8

Semester Study Multiple Comparison: Collaborative Learning Behaviours

\begin{tabular}{lccccc}
\hline (I) Semester & (J) Semester & $\begin{array}{c}\text { Mean difference } \\
(\mathrm{I}-\mathrm{J})\end{array}$ & $\begin{array}{c}\text { Sig. } \\
\text { Semester 1 }\end{array}$ & & \multicolumn{2}{c}{$\begin{array}{c}\text { 95\% Confidence } \\
\text { Interval }\end{array}$} \\
\hline & & & & $\begin{array}{c}\text { Lower } \\
\text { Bound }\end{array}$ & $\begin{array}{c}\text { Upper } \\
\text { Bound }\end{array}$ \\
& Semester 2 & -.21353 & .664 & -.6018 & .1748 \\
& Semester 3 & -.16009 & .887 & -.5416 & .2214 \\
& Semester 4 & -.09975 & .967 & -.4164 & .2169 \\
& Semester 5 & -.51916 & .010 & -.9608 & -.0775 \\
& Semester 6 & -.30161 & .491 & -.7752 & .1720 \\
& Semester 7 & -.63092 & .603 & -1.7170 & .4551 \\
\hline
\end{tabular}

\section{DISCUSSION}

The results of the studies implicated the significant impact of both teaching strategies and learning space design on the collaborative learning behaviour of the students in the classroom. Teaching strategies such as applying facts through multimedia, problem solving and interesting digital content, and the learning space design (LSD) i.e. Effective class size and maintenance of classroom, are a compatible combination in the education process in this millennial era. the LSD suits the needs and character of current learners as 
most of them are technology savvy, prefer more interactive teaching approaches in class and a creative learning process throughout the semesters. The importance of learning space design for $21^{\text {st }}$ century students was also highlighted by several previous authors such as envision (2017); Keppell in (Kujawa-holbrook, 2013), Lippincott (2009) and Nambiar et al. (2017).

The collaborative learning behaviours between male and female students have shown no significant difference, which reflects the insensitivity of gender diversity among the students in different semesters. Thus, the result is not only in tandem with the study done by Atan et al. (2004) but also by the studies of Chyung (2007); price (2006); Rovai \& baker (2005) Sullivan (2001). The participants at Taylor's university seemed to show a positive inclination for collaborative behaviour and team work without issues of gender concerns during their study semesters. They are more focused on enjoying the learning process while getting their work done together with their team members in a harmonious academic environment under the close supervision of their lecturers.

The semester groups however, (year 1 and year 3 students) showed a significant difference in their collaborative learning behaviours. This result could imply that the differences of experience in learning and exposure to the academic environment may have some influence on the students' teamwork or group cohesiveness. The younger students may be more timid and less open towards their peers. As such, they may be not comfortable working in a team that consist $s$ of personalities from different cultural backgrounds. The older students on the other hand, may feel more confident about their abilities, more at ease working with peers, campus facilities and an environment they are familiar with.-

This study highlights the importance of applying different teaching strategies to attract different segments of students while implementing the mobile $\mathrm{x}$-space learning approach. Therefore, the lecturers must be more sensitive to the students' diverse needs and preferences in the classroom every semester, to enable them to create a conducive environment where students can constructively learn new things from their lecturers and their peers. It is practically true that the longer the exposure and the more experience the students have with the mobile $\mathrm{x}$-space learning setup, the more demanding and susceptible to change they may become. They will subsequently transform their collaborative learning behaviour to be either more 
positive or negative, particularly, when they are grouped with other students who share or may not share the same thinking and level of understanding as they have.

In addition, to improve the learning process among the students, the mobile $\mathrm{x}$-space can also help to further enhance the teaching effectiveness of the lecturers, especially in engaging students to harness ideas collectively through active dialogue and team work. In relation to this statement, the results of this study have shown strong positive correlations between both teaching strategies and learning space design with the collaborative learning behaviours demonstrated by the students. Inherently, the mobile x-space learning environment provides many benefits to both students and lecturers which will eventually be reflected in the students' overall learning process at the university. At the same time, it will also free both lecturers and students from an inflexible and unconducive learning process, with a limited space for learning and communication. It could be fair to say that thus the traditional educational approach would no longer be favoured by students who are comfortable with the internet of things in their lives today.

In spite of its limited adoption in the education system especially in malaysia, the uniqueness of a mobile $\mathrm{x}$-space learning setup, as compared with to other traditional education models could be further investigated and explored to ignite the excitement of learning among today's students. Taylor's has transformed to be the best private university with its technology-enabled classrooms in malaysia and the university will continue to strive to be among the most prominent education service providers. Our goal is to provide the best education environment in malaysia. It is hoped that more studies will be conducted to further strengthen the value of mobile learning spaces so that the potential of these learning spaces could be maximised and recognized in the future.

\section{CONCLUSION}

Collaborative learning behaviour can be significantly influenced by the teaching strategies of the lecturers and the learning space design of the classroom. Thus, in contrast to the traditional teaching and learning model, the Mobile X-Space learning paradigm can be one the best methods to enhance students' learning experience in a collaborative setting as this can lead to improved performance in their 
studies. Despite being a new teaching-learning trend particularly in Malaysia, Mobile X-Space learning has been proven to be beneficial to both students and lecturers. It can be turned into a constructive and creative learning experience for today's youth in this new technological era. However, to enable students to learn better and faster, both teaching strategies and learning space design should be applied in tandem by lecturers. The effective use of both approaches can bring about a positive collaborative learning behaviour among students, regardless of genders, and semester groups. Hence, to increase their overall effectiveness, the teaching strategies should be designed to fit the students' needs and preferences, and the usage of Mobile X-Space can be gradually optimized throughout the semesters.

This study can be further extended to a mixed-method design to include both qualitative and quantitative analyses. This would necessitate a. further and deeper exploration to better understand the impact of teaching strategies and Mobile X-Space learning on students' collaborative learning behaviours. Comparisons of studies between local and international universities could also provide a more holistic view of the findings from different perspectives. More importantly, not only would this teaching and learning model influence a student's learning experience and his overall performance, it could also improve the existing pedagogical approach of lecturers. Most important of all, tertiary institutions of learning would need to align their vision and goals to incorporate mobile $\mathrm{x}$-space as an integral part of their present educational policies. This teaching and learning model could also be the catalyst for a more constructive, digitalized learning programme that allows the whole campus to be a potentially effective learning space, at anytime, anywhere, and for everyone. This new teaching and learning model could comfortably also accommodate the multiple demands of students and lecturers within the university's technology-enabled academic environment.

\section{REFERENCES}

Adedokun, O. A., Parker, L. C., Henke, J. N., \& Burgess, W. D. (2017). Student Perceptions of a 21 st Century Learning Space. Journal of Learning Spaces, 6(1), 1-13.

Ahlefeldt, F. (2017). Vygotsky and the benefits of collaborative learning. Retrieved October 15, 2018, from https:// consiliumeducation.com/itm/2017/01/04/two-or-more-headsare-better-than-one/ 
Ahmad Ibrahim. (2017). Society demands more from our universities I New Straits Times I Malaysia General Business Sports and Lifestyle News. Retrieved August 20, 2018, from https:// www.nst.com.my/news/2017/03/216733/society-demandsmore-our-universities

Armstrong,S.(2013).The 10mostimportantteaching strategies.Retrieved November 27, 2018, from http://www.innovatemyschool.com/ ideas/the-10-most-powerful-teaching-strategies

Atan, H., Sulaiman, F., Rahman, Z. A., \& Idrus, R. M. (2004). Gender Differences in Availability, Internet Access and Rate of Usage of Computers among Distance Education Learners. Educational Media International. https://doi. org/10.1080/09523980210166459

Brown, J. S., \& Adler, R. P. (2008). Minds on Fire: Open Education, the Long Tail, and Learning 2.0. Educause Review.

Caro, D. H., Lenkeit, J., \& Kyriakides, L. (2016). Teaching strategies and differential effectiveness across learning contexts: Evidence from PISA 2012. Studies in Educational Evaluation, 49, 30-41. https://doi.org/10.1016/J.STUEDUC.2016.03.005

Cashin, W. E. (1995). Student Ratings of Teaching: The Research Revisited. No. IDEA Paper.

CEI. (2018). Active Learning. Retrieved November 30, 2018, from https://cei.umn.edu/active-learning

Cobern, W. W. (1993) Constructivism, Journal of Educational and Psychological Consultation, 4:1, 105-112, DOI: 10.1207/ s1532768xjepc0401_8

Cohen, J. (1988). Statistical power analysis for the behavioral sciences. Second Edition. Hillsdale, NJ: Lawrence Erlbaum Associates, Publishers.

Cronbach, L. J. (1951). Coeffiecient alpha and the internal structure of test. Psychometrika. https://doi.org/10.1007/bf02310555

Eison, J. (2010). Using Active Learning Instructional Strategies to Create Excitement and Enhance Learning. Retrieved from http://citeseerx.ist.psu.edu/viewdoc/download?doi=10.1.1.45 6.7986\&rep=rep1\&type $=$ pdf

Envision. (2107). 6 Key Elements of 21 st Century Classroom Design. Retrieved July 23,2018, from https://www.envisionexperience. $\mathrm{com} / \mathrm{blog} / 6$-key-elements-of-21 st-century-classroom-design

Hacisalihoglu, G., Stephens, D., Johnson, L., \& Edington, M. (2018). The use of an active learning approach in a SCALEUP learning space improves academic performance in undergraduate General Biology. PLoS ONE, 13(5), 1-14. https://doi.org/10.1371/journal.pone.0197916 
Harvey, E. J., \& Kenyon, M. C. (2013). Classroom Seating Considerations for 21 st Century Students and Faculty. Journal of Learning Spaces, 2(1). Retrieved from http://libjournal. uncg.edu/jls/article/view/578/454

Jelas, Z. M., Salleh, A., Azman, N., Jani, R., Hamzah, R., Mahmud, I., ... Hamzah, H. (2014). Gender Differences in Learning Support And Academic Achievement: The Mediating Role of Student Engagement. Malaysian Journal of Learning and Instruction (Vol. 11). Retrieved from http://mjli.uum.edu.my/ Khong, H. K., Hassan, N. H., \& Ramli, N. (2017). Motivation and gender differences in learning Spanish as a foreign language in a Malaysian Technical University. Malaysian Journal of Learning and Instruction.

Kujawa-Holbrook, S. A. (2013). Physical and Virtual Learning Spaces in Higher Education: Concepts for the Modern Learning Environment. By Mike Keppell, Kay Souter, and Matthew Riddle. Hershey, Pa.: Information Science Reference, 2012. xxi + 236 pages. ISBN 978-1-60960-114-0. \$180.00. Teaching Theology \& Religion, 16, e36-e37. https:// doi.org/10.1111/teth.12084

Li, Q. (1999). Teachers' beliefs and gender differences in mathematics: A review. Educational Research. https://doi. org/10.1080/0013188990410106

Lippincott, J. (2009). Learning Spaces: Involving Faculty to Improve Pedagogy I EDUCAUSE. Retrieved August 27, 2018, from https://er.educause.edu/articles/2009/3/learning-spacesinvolving-faculty-to-improve-pedagogy

McLeod, S. (2018). Vygotsky I Simply Psychology. Retrieved October 15, 2018, from https://www.simplypsychology.org/ vygotsky.html

Md-Ali, R., Bi, H. B., Karim, A., \& Yusof, F. M. (2016). Experienced Primary School Teachers' Thoughts on Effective Teachers of Literacy and Numeracy. Malaysian Journal of Learning and Instruction (Vol. 13). Retrieved from http://mjli.uum.edu.my Meyer, O. (2010). Towards quality-CLIL: Successful planning and teaching strategies. Pulso.

Nambiar, R., Noorizah, M. N., Kemboja, I., \& Shahirah, A. (2017). New Learning Spaces and Transformations in Teacher Pedagogy and Student Learning Behavior in the Language Learning Classroom, 23(4), 29-40.

Nokes-Malach, T. J., Richey, J. E., \& Gadgil, S. (2015). When Is It Better to Learn Together? Insights from Research on 
Collaborative Learning. Educational Psychology Review, 27(4), 645-656. https://doi.org/10.1007/s10648-015-9312-8

Nunnally, J. C. (1978). Psychometric Theory. New York: McGrawHill. https://doi.org/10.1037/018882

Oblinger, D. G. (2007). Space as a change agent. Learning Spaces, 2-3. https://doi.org/10.1007/978-3-642-01039-2

OECD. (2016). Teaching Strategies for Instructional Quality Insights

From The Talis-Pisa Link Data. Retrieved from http://www. oecd.org/education/school/TALIS-PISA-LINK-teaching_ strategies_brochure.pdf

Pett, M. A., Lackey, N. R. and Sullivan, J. J. (2003) Making Sense of Factor Analysis: The Use of Factor Analysis for Instrument Development in Health Care Research. SAGE Publications, Thousand Oaks.

Saavedra, A. R., \& Opfer, V. D. (2012). Teaching and Learning 21st Century Skills: Lessons from the Learning Sciences. Asia Society, 35.

Scott, C. L. (2015). Working Papers Preparing Learners for 21st Century Competencies and Skils Overall Vision ofTwenty-First Century Pedagogy Conclusions. Next Steps and Future Issues, Issues the Futures of Learning 3: What Kind of Pedagogies for the 21st Century? Retrieved from http://repositorio.minedu. gob.pe/bitstream/handle/123456789/3747/The Futures of Learning 3 what kind of pedagogies for the 21 st century. pdf? sequence $=1 \&$ is Allowed $=\mathrm{y}$

Shapiro, S. S., \& Wilk, M. B. (1965). An Analysis of Variance Test for Normality (Complete Samples). Biometrika. https://doi. org/10.2307/2333709

Smith, L., MacGregor, J. T., Smith, B. L., \& MacGregor, J. T. (1992). What is collaborative Learning? Collaborative Learning: A Sourcebook for Higher Education.

Sugeng, B., \& Wilujeng Suryani, A. (2018). Presentation-Based Learning and Peer Evaluation To Enhance Active Learning And Self-Confidence In the Financial Management Classroom. Malaysian Journal of Learning and Instruction (Vol. 15). Retrieved from http://mjli.uum.edu.my/images/vol15New/ Bab7-Presentation-Based-Learning-And-Peer-EvaluationTo-Enhance-Active-Learning-And-Self-Confidence.pdf

Sulisworo, D. (2012). The Effect of Gender and Online Collaborative Learning Strategy to Student Learning Motivation. International Journal of Learning \& Development, 2(6). https://doi.org/10.5296/ijld.v2i6.1989 
Tulbure, C. (2012). Learning styles, teaching strategies and academic achievement in higher education: A cross-sectional investigation. Procedia-Social and Behavioral Sciences, 33, 0-000. https://doi.org/10.1016/j.sbspro.2012.01.151

Walker, J. D., Brooks, D.C. \& Baepler, P. (2011). Pedagogy and space: Empirical research on new learning environments. EDUCAUSE Quarterly, 34(4). Retrieved from https:// er.educause.edu/articles/2011/12/pedagogy-and-spaceempirical-research-on-new-learning-environments 